\title{
ANALISIS PENERIMAAN MAHASISWA UKSW TERHADAP PENGGUNAAN iSALATIGA MENGGUNAKAN TECHNOLOGY ACCEPTANCE MODEL (STUDI KASUS : DINAS PERPUSTAKAAN DAN KEARSIPAN KOTA SALATIGA)
}

\author{
Paulo Emilio Thenu ${ }^{1)}$ dan Melkior N. N. Sitokdana ${ }^{2)}$ \\ ${ }^{1,2}$ Program Studi Sistem Informasi, Fakultas Teknologi Informasi, Universitas Kristen Satya Wacana \\ ${ }^{1,2}$ Jalan Diponegoro No. 52-60, Salatiga, 50711, Telp: (0298) 321212, Indonesia \\ E-mail: paulo.3milio@gmail.com ${ }^{1)}$, melkior.sitokdana@uksw.edu ${ }^{2)}$
}

\begin{abstract}
ABSTRAK
Aplikasi iSalatiga merupakan platform media sosial yang diluncurkan oleh Dinas Perpustakaan dan Kearsipan Kota Salatiga (DINPERSIP). Aplikasi iSalatiga membuat penggunanya lebih efisisen dalam membaca. iSalatiga bisa diakses melalui PC, dekstop, dan mobile (smartphone-based application). Tujuan dari penelitian ini adalah untuk menganalisa penerimaan mahasiswa UKSW terhadap penggunaan aplikasi iSalatiga dengan menggunakan Technology Acceptance Model (TAM). Digunakan metode deskriptif kuantitatif pada penelitian ini, dengan membagi kuesioner kepada pengunjung perpustakaan Kota Salatiga. Dari hasil penelitian ini, dapat disimpulkan bahwa penerimaan mahasiswa UKSW terhadap penggunaan aplikasi iSalatiga ditentukan oleh 3 variabel yang saling mempunyai pengaruh positif. Yaitu pengaruh positif antara persepsi kemudahan pengguna (Perceived Ease of Use) dengan sikap pengguna (Attitude Toward) terhadap iSalatiga, pengaruh positif antara sikap pengguna (Attitude Toward) dengan niat perilaku untuk menggunakan (Behavioral Intention) aplikasi iSalatiga, dan pengaruh positif antara niat perilaku untuk menggunakan (Behavioral Intention) dengan kondisi sesunggunya (Actual Use) dalam menggunakan iSalatiga secara nyata.
\end{abstract}

Kata Kunci: DINPERSIP, iSalatiga, Technology Acceptance Model

\section{PENDAHULUAN}

Pada era globalisasi kemajuan pada teknologi informasi terus berkembang sangat pesat yang tanpa di sadari sangatlah berpengaruh terhadap berbagai kehidupan yang ada pada dunia ini. Salah satunya perpustakaan. Perkembangan teknologi informasi mempunyai peran penting terhadap perpustakaan dalam memberikan informasi maupun dalam mengelolah layanan perpustakaan. Apabila yang dulunya masih dilakukan dengan cara manual kini telah dilakukan secara digital yang dapat diakses lewat jaringan komputer maupun menggunakan ponsel yang kita miliki.

Dinas Perpustakaan dan Kearsipan Kota Salatiga (DINPERSIP) merupakan salah satu perpustakaan yang sudah menerapkan peran teknologi informasi dalam melakukan pengembangan kinerja layanan perpustakaan yang lebih efisien. DINPERSIP Kota Salatiga sudah banyak merancang dan meluncurkan berbagai produk inovasi untuk memenuhi kepuasan dan kemudahan layanan pengguna perpustakaan salah satunya aplikasi iSalatiga. iSalatiga merupakan buku digital yang dapat diakses melalui pc, dekstop dan mobile (smartphonebased application). Aplikasi ini telah dikenalkan dalam berbagai kegiatan yang melibatkan DINPERSIP Kota Salatiga dan melalui beberapa media sosial maupun pada website resmi Dinas Perpustakaan dan Kearsipan Kota Salatiga. Pada penerapannya, aplikasi iSalatiga tentu saja sudah berjalan dengan baik hanya saja masih sebagian anggota maupun pengunjung belum mengetahui tentang adanya aplikasi iSalatiga yang tentunya sangat memudahkan penggunanya dalam mengetahui informasi maupun dalam proses peminjaman buku. Terbukti sejak launching pada bulan juli 2017 hingga sekarang aplikasi iSalatiga hanya mencapai 100 unduhan.

Tujuan penelitian ini untuk menganalisis penerimaan mahasiswa/i UKSW terhadap penggunaan aplikasi iSalatiga dengan menggunakan Technology Acceptance Model (TAM). Adapun beberapa penelitian terdahulu yang dijadikan sebagai pedoman dalam penelitian ini antara lain:

Penelitian berjudul Analisis Technology Acceptance Model (TAM) Terhadap Pengguna Sistem Informasi di Nusa Dua Beach Hotel \& Spa. Tujuan penelitian ini untuk mengetahui pengaruh personalization, computer self efficacy, dan trust terhadap pengguna sistem informasi. Jumlah sampel yang digunakan sebanyak 41 informan dengan menggunakan purposive sampling dalam pengambilan sampel dan menggunakan rumus slovin dalam melakukan perhitungan sampel. Penelitian ini menunjukan bahwa trust dan computer self efficacy berpengaruh positif terhadap manfaat (perceived usefulness) dan kemudahan pengguna (perceived ease of use), sedangkan personalization tidak memiliki pengaruh terhadap keduanya (Ni Luh Nyoman Sherina Devi and I Wayan Suartana, 2014). 
Penelitian berjudul Penerapan Analisis Penerimaan Teknologi Smart city Kota Purwekerto Dengan Model Technology Acceptance Model (TAM). Digunakan pendekatan kuantitatif pada penelitian ini dengan jumlah sampel yang digunakan sebanyak 400 sampel. Masingmasing terbagi dari pria yaitu sebanyak 216 orang dan wanita yaitu sebanyak 164 orang. Diketahui hasil dari penelitian ini menunjukan bahwa bahwa persepsi kemudahan berpengaruh signifikan terhadap persepsi kemanfaatan dalam penerimaan teknologi smart city, persepsi kemudahan berpengaruh signifikan terhadap kebiasaan yang menunjukan keinginan untuk menggunakan teknologi smart city, dan persepsi kemudahan penggunaan aplikasi smart city akan mempengaruhi sikap pengguna dalam menggunakan teknologi smart city (Hendro Gunawan and Lynawati, 2018).

Penelitian berjudul Technology Acceptance Model (TAM) Dalam Pengujian Model Penerimaan Sistem Informasi Keuangan Daerah. Tujuan penelitian ini untuk mengetahui apakah sisi pada pengguna SIPKD dapat diterima sebagai sebagai suatu sistem yang meningkatkan kinerja. Jumlah sampel yang digunakan yaitu sebanyak 67 orang sampel yang melibatkan instasi di wilayah Provinsi Daerah Istimewa Yogyakarta. Hasil penelitian ini diketahui bahwa keberhasilan penerimaan SIPKD tergantung pada persepsi pengguna. Apabila pengguna merasakan kemudahan menggunakan SIPKD dan merasa memiliki adanya manfaat maka mereka akan sangat mudah untuk menerima SIPKD dalam melakukan suatu pekerjaan (Fran Sayekti \& Pulasna Putarta, 2016).

Berbeda dengan penelitian yang sebelumnya, digunakan metode kuantitatif dalam melakukan penelitian ini yang mengacu pada konstruk Technology Acceptance Model (TAM). Beberapa konsrtuk yang akan digunakan penulis antara lain Perceived usefulness, Perceived ease of use, Attitude Toward, Behavioral Intention, dan Actual Use sehingga penulis depat menguji tingkat penerimaan mahasiswa/i UKSW terhadap aplikasi iSalatiga yang merupakan pengunjung Dinas Pepustakaan dan Kearsipan Kota Salatiga.

\section{RUANG LINGKUP}

Ruang lingkup pada penelitian ini yaitu:

1. Jangkauan permasalahan dalam penelitian ini adalah implementasi dalam penggunaan aplikasi iSalatiga apakah sudah efisien bagi pengunjung perpustakaan dalam membantu mengerjakan tugas maupun pekerjaan lainnya.

2. Batasan penelitian ini hanya fokus kepada 25 mahasiswa/i UKSW pengunjung perpustakaan kota Salatiga yang pernah menggunakan aplikasi iSalatiga atau paling tidak memiliki pengetahuan tentang $e$ book.

3. Rencana dari hasil penelitian ini yaitu untuk mengetahui penerimaan mahasiswa/i UKSW, dalam hal ini pengunjung perpustakaan terhadap penggunaan aplikasi iSalatiga sehingga bisa dijadikan sebagai acuan pengembangan aplikasi kedepannya.

\section{BAHAN DAN METODE}

Adapun studi literatur, metode dan tahapan penelitian:

\subsection{Technology Acceptance model}

Technology Acceptance model (TAM) pertama kali diperkenalkan oleh Davis Fred D. Davis pada tahun 1989, dilandasi oleh Theory of Reasoned (TRA). TRA merupakan model yang lebih mempelajari tentang psikologi sosial seseorang yang dilakukannya secara sadar. Adapun tujuan dari TAM, yaitu tentang memprediksi dan menjelaskan penerimaan pengguna teknologi informasi yang berdasarkan dari dua persepsi yakni persepsi kemanfaatan pengguna (Perceived Usefulness) dan persepsi kemudahan pengguna (Perceived ease of use).

Tujuan utama TAM adalah untuk menjelaskan dan memprediksi penerimaan penggunaan terhadap teknologi. TAM mampu mengidentifikasi penerimaan pengguna terhadap suatu teknologi, berdasarkan dua faktor yaitu meliputi persepsi kemanfaatan pengguna (Perceived usefulness) dan persepsi kemudahan pengguna (Perceived ease of use).

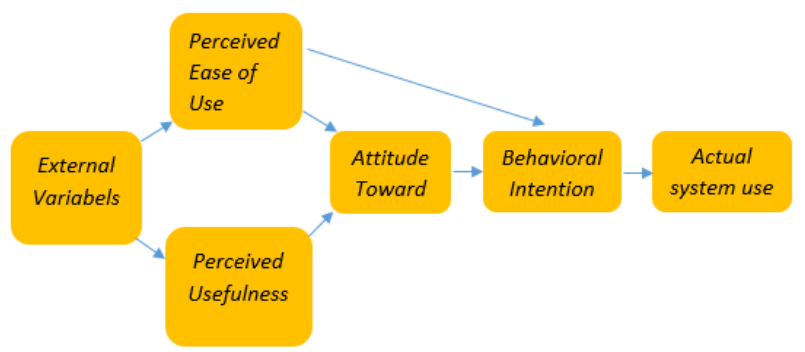

Gambar 1. Technology Acceptance Model

Dalam konsep TAM, terdapat lima penyusun yang sangat cenderung dalam mempengaruhi psikologi seseorang terhadap penggunaan teknologi informasi.

Persepsi kemanfaatan pengguna (Perceived Usefulness) adalah keadaan dimana psikologi penggunanya percaya bila menggunakan teknologi informasi maka akan meningkatkan kinerjanya.

Persepsi kemudahan pengguna (Perceived ease of use) adalah keadaan dimana psikologi penggunanya percaya dengan mudahnya menggunakan teknologi informasi tanpa harus menggunakan usaha yang berlebihan.

Sikap pengguna (Attitude Toward) adalah sikap pengguna tentang penggunaan teknologi informasi baik itu tentang penerimaan maupun tentang penolakan.

Niat perilaku menggunakan (Behavioral intention) adalah keadaan dimana kecenderungan perilaku yang menyebabkan untuk tetap berniat menggunakan teknologi informasi secara terus menerus.

Kondisi sesungguhnya (Actual use) adalah kondisi penggunaan teknologi informasi secara real atau nyata. 


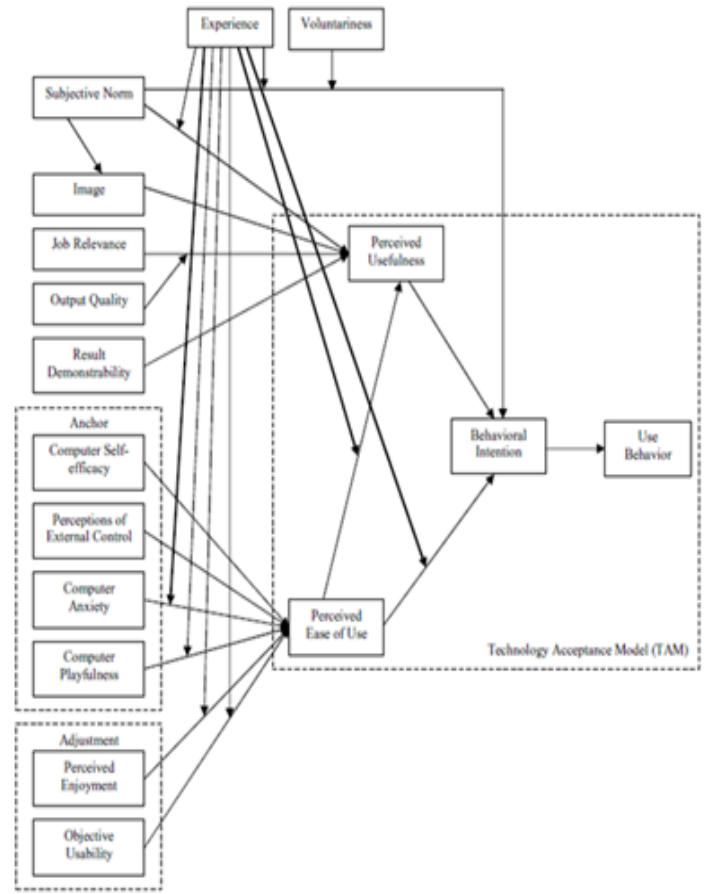

Gambar 2. Technology Acceptance Model 3

Gambar 2 merupakan versi akhir dari pengembangan Technology Acceptance Model (TAM) yang dilakukan oleh Venkatesh dan Bala pada tahun 2008. TAM3 merupakan gabungan dari pengembangan Technology Acceptance Model 2, TAM3 juga mempunyai kesamaan dengan TAM1 dan TAM2 yaitu sama-sama memiliki dua variabel yakni persepsi kemanfaatan pengguna (Perceived Usefulness) dan persepsi kemudahan pengguna (Perceived ease of use) (Agung Prasetyo Patara, 2016).

\subsection{Metode Penelitian}

Pada penelitan ini, pendekatan kuantitatif di gunakan sebagai acuan dalam mengkaji data. Pendekatan kuantitatif ialah penelitian dimana lebih berfokus pada data-data numerial yang diolah menggunakan metodemetode statistika. Defenisi dari penelitian kuantitatif ialah penelitian pendekatan untuk menguji teori objektif dengan memeriksa hubungan antara variabel yang dapat diukur menggunakan prosedur statistik (Creswell, 2014). Terdapat 5 tahapan yang dilakukan untuk mencapai hasil penelitian yaitu:

1. Observasi

Tahapan pertama meliputi observasi lapangan ke Dinas Perpustakaan dan Kearsipan Kota Salatiga (DINPERSIP) untuk mengidentifikasi masalah-masalah yang ada pada penerapan aplikasi iSalatiga.

2. Studi Literatur

Tahapan kedua meliputi mencari literatur yang berkaitan dengan penelitian untuk mengetahui tentang penerimaan mahasiswa/i UKSW terhadap penggunaan iSalatiga.

3. Pengambilan Data
Tahapan ketiga meliputi pengumpulan data pada tempat penelitian (Profil tempat penelitan) dan juga menyebarkan kuesioner kepada 25 mahasiswa UKSW, dalam hal ini pengunjung perpustakaan yang sudah pernah mencoba menggunakan iSalatiga dan paling tidak memiliki pengetahuan tentang $e$-book.

4. Pengolahan Data

Tahapan keempat meliputi pengolahan data yang telah di dapatkan melalui kuesioner yang telah di isi oleh 25 responden mahasiswa/i UKSW. Data yang diolah akan di input melalui aplikasi SPSS versi 16 untuk mengetahui hasil hitungan statistik.

5. Kesimpulan dan Saran

Dan pada tahapan yang kelima, akan dilakukan pengambilan keputusan, kesimpulan dan saran yang sesuai dengan hipotesis menurut konsep yang ada pada Technology Acceptance Model (TAM) dengan megacu pada hasil perhitungan lewat aplikasi SPSS versi 16.

\section{PEMBAHASAN}

Aplikasi iSalatiga merupakan merupakan buku digital yang bisa diakses melalui PC, dekstop dan mobile (smartphone-based application) sehingga bisa diakses kapan saja tanpa harus ribet. Aplikasi ini dirilis pada juli 2017.

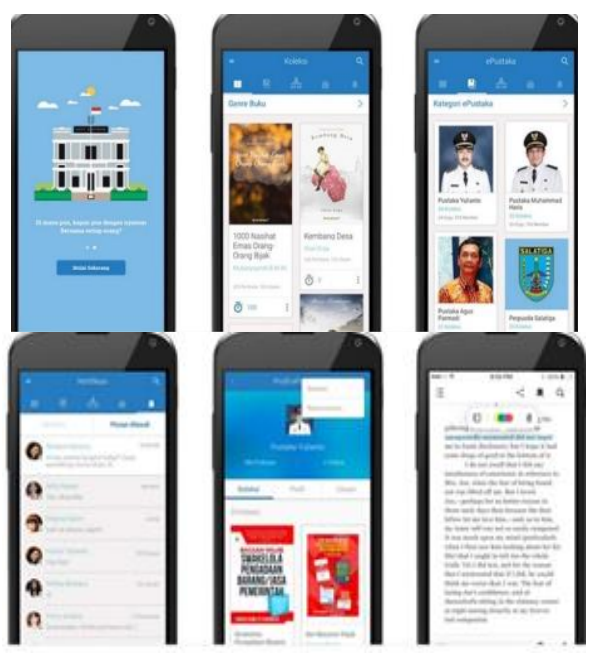

Gambar 3. Tampilan aplikasi iSalatiga

Gambar 3 merupakan tampilan aplikasi iSalatiga dan berbagai fitur yang tersedia. Untuk dapat mengakses iSalatiga penggunanya hanya perlu mendaftar dengan menggunakan akun email ataupun facebook yang tentunya masih dapat digunakan dalam kegiatan seharihari. Terdapat fitur e-reader untuk memudahkan penggunanya dapat membaca secara langsung dan juga memungkinkan penggunanya dalam membangun komunitas antara sesama pembaca melalui fitur inbox, like, coment, share, dan follow/unfollow yang sudah tersedia didalam aplikasi iSalatiga.

\subsection{Identifikasi Responden}

Dari hasil pengumpulan data lewat kuesioner yang dibagikan kepada 25 informan mahasiswa/i UKSW, 
dalam hal ini pengunjung perpustakaan Kota Salatiga yang pernah mencoba menggunakan aplikasi iSalatiga sebelumnya dan paling tidak memiliki pengetahuan tentang $e$-book.

Tabel 1. Respoden berdasarkan fakultas

\begin{tabular}{|c|c|c|}
\hline Fakultas & Frequency & Percent \\
\hline BIOLOGI & 1 & $4 \%$ \\
\hline FBS & 1 & $4 \%$ \\
\hline FEB & 3 & $12 \%$ \\
\hline FISKOM & 2 & $8 \%$ \\
\hline FTI & 6 & $24 \%$ \\
\hline HUKUM & 2 & $8 \%$ \\
\hline FKIK & 2 & $8 \%$ \\
\hline PSIKOLOGI & 1 & $4 \%$ \\
\hline TEOLOGI & 7 & $28 \%$ \\
\hline Total & 25 & $100.0 \%$ \\
\hline
\end{tabular}

Terlihat pada tabel 1 dari keikutsertaan 25 responden sebagian besar yaitu mahasiswa/i Fakultas Teologi yang jumlah responden sebanyak 7 orang dengan presentase sebesar 28\%, diikuti dengan mahasiswa/i Fakultas Teknologi Informasi (FTI) sebanyak 6 orang dengan presentase sebesar 24\%, kemudian dari mahasiswa/i Fakultas Ekonomika dan Bisnis (FEB) sebanyak 3 orang dengan presentase sebesar 12\%. Sedangkan untuk mahasiswa/i Fakultas Hukum, Fakultas Ilmu Sosial dan Ilmu Komunikasi (Fiskom), Fakultas Kedokteran dan Fakultas Ilmu Kesehatan memiliki jumlah responden yang sama yaitu sebanyak 2 orang dengan presentase sebesar 8\%. Kemudian untuk mahasiswa/i Fakultas Biologi, Fakultas Psikologi, dan Fakultas Bahasa dan Seni (FBS) juga memiliki masing-masing responden yang sama yakni sebanyak 1 orang dengan presentase sebesar $4 \%$.

Tabel 2. Crosstabulation antara variabel Jenis kelamin dengan variabel Fakultas

\begin{tabular}{|c|c|c|}
\hline Fakultas & $\begin{array}{c}\text { Jenis Kelamin } \\
\text { Laki-Laki }\end{array}$ & $\begin{array}{c}\text { Jenis Kelamin } \\
\text { Perempuan }\end{array}$ \\
\hline BIOLOGI & 0 & 1 \\
\hline FBS & 0 & 1 \\
\hline FEB & 1 & 2 \\
\hline FISKOM & 1 & 1 \\
\hline FTI & 4 & 2 \\
\hline HUKUM & 1 & 1 \\
\hline FKIK & 1 & 1 \\
\hline PSIKOLOGI & 0 & 1 \\
\hline TEOLOGI & 2 & 5 \\
\hline TOTAL & 10 & 15 \\
\hline
\end{tabular}

Tabel 2 berisi tabulasi silang (crosstabulation) antara variabel jenis kelamin dengan fakultas. Terlihat pada tabel
2 diatas, total jumlah informan yang berjenis kelamin lakilaki yakni sebanyak 10 orang kemudian untuk total jumlah informan yang berjenis kelamin perempuan yakni sebanyak 15 orang. Fakultas Teknologi Informasi (FTI) merupakan informan pria terbanyak yaitu sebanyak 4 orang. sedangkan Fakultas Teologi merupakan informan wanita terbanyak yaitu sebanyak 5 orang.

\subsection{Uji Validitas}

Uji validitas merupakan suatu data yang dapat diuji kebenarannya sesuai dengan instrumen-instrumen yang dapat digunakan untuk mengukur ketepatan antara data yang sesungguhnya terjadi pada objek dengan data yang dikumpulkan oleh peneliti. (Sugiono, 2014). Dalam melakukan uji validitas yang ada pada penelitian ini, penulis menggunakan aplikasi SPSS versi 16. Kemudian untuk mengetahui valid atau tidaknya kuesioner, dapat dilakukan dengan membandingkan nilai $r$ hitung melalui data analisis yang telah diketahui pada kolom tabel Correction Item-TotaL Corelation dengan mengacu pada nilai $r$ tabel. Pertanyaan akan dinyatakan valid jika nilai $r$ hitung lebih besar dari nilai $\mathrm{r}$ tabel, sedangkan apabila nilai $r$ hitung lebih kecil dari nilai $r$ tabel maka pertanyaan akan dinyatakan tidak valid. Perhitungan dari nilai $r$ tabel didasari oleh nilai Degree of Freedom (df) yaitu $\mathrm{df}=\mathrm{n}-2$ dengan sig sebesar 5\%. Sesuai dengan jumlah sampel dalam penelitian ini, maka nilai $\mathrm{df}=25-2=2$. Dengan demikian kita dapat melihat berdasarkan dengan ketentuan nilai Degree of Freedom (df). Maka ditemukan nilai $\mathrm{r}$ tabel untuk n 23 pada signifikansi 5\% adalah sebesar 0,413 .

Tabel 3. Uji Validitas

\begin{tabular}{|c|c|}
\hline Variabel & $\begin{array}{c}\text { Corrected item-total } \\
\text { correlation }\end{array}$ \\
\hline PEU1 & .819 \\
\hline PEU2 & .464 \\
\hline PEU3 & .329 \\
\hline PEU4 & .651 \\
\hline PU1 & .556 \\
\hline PU2 & .823 \\
\hline PU3 & .714 \\
\hline PU4 & .586 \\
\hline AT1 & .661 \\
\hline AT2 & .878 \\
\hline AT3 & .810 \\
\hline AT4 & .722 \\
\hline BI1 & .871 \\
\hline $\mathrm{BI} 2$ & 677 \\
\hline $\mathrm{BI} 3$ & .872 \\
\hline BI4 & .878 \\
\hline
\end{tabular}




\begin{tabular}{|l|l|}
\hline AU1 & .887 \\
\hline AU2 & .691 \\
\hline AU3 & .129 \\
\hline AU4 & .721 \\
\hline
\end{tabular}

Hasil ouput SPSS pada tabel 3 uji validitas, diketahui pada kolom Corrected Item-Total Correlation menunjukan bahwa variabel PEU3 dan AU3 belum mencapai atau masih kurang dari nilai $r$ tabel yaitu sebesar 0,413 sehingga kedua variabel tersebut harus di buang atau dihapus karena dinyatakan tidak valid.

Tabel 4. Uji Validitas kedua

\begin{tabular}{|c|c|}
\hline Variabel & $\begin{array}{c}\text { Corrected item-total } \\
\text { correlation }\end{array}$ \\
\hline PEU1 & .800 \\
\hline PEU2 & .466 \\
\hline PEU4 & .661 \\
\hline PU1 & .567 \\
\hline PU2 & .823 \\
\hline PU3 & .748 \\
\hline PU4 & .584 \\
\hline AT1 & .678 \\
\hline AT2 & .877 \\
\hline AT3 & .804 \\
\hline AT4 & .737 \\
\hline BI1 & .853 \\
\hline BI2 & .646 \\
\hline BI3 & .877 \\
\hline BI4 & .863 \\
\hline AU1 & .886 \\
\hline AU2 & .703 \\
\hline AU4 & .757 \\
\hline
\end{tabular}

Setelah membuang variabel yang dinyatakan tidak valid yaitu variabel PEU3 dan AU3, maka dilakukan lagi uji validitas kedua untuk melihat apakah masih ada variabel yang belum mencukupi atau kurang dari nilai $r$ tabel. Seperti pada tabel 4 diatas, hasil output SPSS uji validitas kedua menyatakan semua variabel telah melebihi nilai $r$ tabel yaitu sebesar 0,413 sehingga dinyatakan valid.

\subsection{Uji Reliabilitas}

Uji reliabilitas dapat dilakukan secara bersamaan terhadap semua item pertanyaan dalam kuesioner penelitian (V Wiratna Sujarweni, 2015). Untuk mengetahui reliabel atau konsisten kuesioner penelitian ini, dapat dilihat pada kolom tabel Cronbach's Alpha Item Deleted jika nilai pada kolom tabel Cronbach's Alpha Item Deleted lebih dari 0,60 maka akan dinyatakan reliabilitas, sedangkan jika nilai pada kolom tabel
Cronbach's Alpha Item Deleted kurang dari 0,60 maka akan dinyatakan tidak reliabilitas.

Tabel 5. Reliabilitas Nilai Alpha
\begin{tabular}{|c|c|}
\hline Variabel & $\begin{array}{c}\text { Cronbach's Alpha } \\
\text { Item Deleted }\end{array}$ \\
\hline PEU1 & .956 \\
\hline PEU2 & .961 \\
\hline PEU3 & .958 \\
\hline PU1 & .959 \\
\hline PU2 & .956 \\
\hline PU3 & .956 \\
\hline PU4 & .959 \\
\hline AT1 & .957 \\
\hline AT2 & .955 \\
\hline AT3 & .956 \\
\hline AT4 & .957 \\
\hline BI1 & .955 \\
\hline BI2 & .958 \\
\hline BI3 & .955 \\
\hline BI4 & .955 \\
\hline AU1 & .954 \\
\hline AU2 & .957 \\
\hline AU4 & .956 \\
\hline
\end{tabular}

Tabel 5 di atas mendeskripsikan tentang output statistik nilai alpha pada 18 item variabel pertanyaan kuesioner. Nilai alpha pada 18 item variabel pertanyaan dinyatakan > nilai minimal pada kolom tabel Cronbach's Alpha Item Deleted yakni sebesar 0,60 sehingga ke-18 item pertanyaan kuesioner dinyatakan reliabel atau konsisten.

\subsection{Uji Hipotesis}

Pengujian hipotesis ini dilakukan menggunakan rumus $\mathrm{t}$ tabel $=\mathrm{t}(\mathrm{a} / ; \mathrm{n}-\mathrm{k}-1)$ dengan demikian sesuai kasus dalam penelitian ini $\mathrm{t}$ tabel $=(0,025: 23)=2,069$. Dilakukan pengambilan dasar keputusan dengan cara tabel nilai $\mathrm{t}$ hitung harus dibandingkan dengan nilai $\mathrm{r}$ tabel. Apabila nilai sig $<0,5$ maka mempunyai pengaruh yang relevan sehingga hipotesis diterima. Namun apabila nilai sig > 0,5 dapat dinyatakan tidak mempunyai pengaruh yang relevan sehingga hipotesis ditolak.

Tabel 6. Uji Hipotesis

\begin{tabular}{|c|c|c|}
\hline Variabel & T & Sig \\
\hline PEU to AT & 2.178 & .161 \\
\hline PU to AT & .623 & .597 \\
\hline PU to BI & .009 & .993 \\
\hline AT to BI & 5.815 & .028 \\
\hline BI to AU & 9.352 & .003 \\
\hline
\end{tabular}

Uji hipotesis 1 menyatakan bahwa adanya pengaruh yang positif antara persepsi kemudahan pengguna (Perceived Ease of Use) dengan sikap pengguna (Attitude Toward). Diketahui nilai t hitung pada PEU (Perceived 
Ease of Use) to AT (Attitude Toward) dalam tabel 6 Uji Hipotesis yakni sebesar 2.178 kemudian untuk nilai sig pada PEU (Perceived Ease of Use) to AT (Attitude Toward) yakni sebesar 161, yang berarti hipotesis diterima.

Uji hipotesis 2 menyatakan bahwa tidak adanya pengaruh yang positif antara persepsi kemanfaatan pengguna (Perceived Usefulness) dengan sikap pengguna (Attitude Toward). Diketahui nilai t hitung pada PU (Perceived Usefulness) to AT (Attitude Toward) dalam tabel 6 Uji Hipotesis yakni sebesar 623 kemudian untuk nilai sig pada PU (Perceived Usefulness) to AT (Attitude Toward) yakni sebesar 597, yang berarti hipotesis ditolak.

Uji hipotesis 3 menyatakan bahwa tidak adanya pengaruh yang positif antara persepsi kemanfaatan pengguna (Perceived Usefulness) dengan niat perilaku menggunakan (Behavioral Intention). Diketahui nilai $\mathrm{t}$ hitung pada PU (Perceived Usefulness) to BI (Behavioral Intention) dalam tabel 6 Uji Hipotesis yakni sebesar 009 kemudian untuk nilai sig pada PU (Perceived Usefulness) to (Behavioral Intention) yakni sebesar 993, yang berarti hipotesis ditolak.

Uji hipotesis 4 menyatakan bahwa adanya pengaruh yang positif antara sikap pengguna (Attitude Toward) dengan niat perilaku menggunakan (Behavioral Intention). Diketahui nilai t hitung pada AT (Attitude Toward) to BI Behavioral dalam tabel 6 Uji Hipotesis yakni sebesar 5.815 kemudian untuk nilai sig pada AT (Attitude Toward) to BI (Behavioral Intention) yakni sebesar 028, yang berarti hipotesis diterima.

Uji hipotesisdsdff 5 menyatakan bahwa adanya pengaruh yang positif antara niat perilaku menggunakan (Behavioral Intention) dengan kondisi sesunggunya (Actual Use). Diketahui nilai t hitung pada niat perilaku menggunakan (Behavioral Intention) to kondisi sesungguhnya (Actual Use) dalam tabel 6 Uji Hipotesis yakni Sebesar 9.352 kemudian untuk nilai sig pada BI (Behavioral Intention) to AU (Actual Use) yakni sebesar 003, yang berarti hipotesis diterima.

\section{KESIMPULAN}

Berdasarkan hasil penelitian dan pembahasan maka dapat disimpulkan bahwa tingkat penerimaan mahasiswa/i UKSW terhadap aplikasi iSalatiga sangat dipengaruhi oleh 3 variabel yang masing-masing mempunyai pengaruh yang positif di antara keduaduanya. Yaitu, Pengaruh persepsi kemudahan pengguna (Perceived ease of use) dengan sikap pengguna (Attitude Toward) terhadap iSalatiga. Yang berarti pengguna iSalatiga percaya dengan menggunakan iSalatiga akan terasa lebih mudah sehingga mampu mengurangi usaha dalam mengerjakan suatu pekerjaan, Pengaruh sikap pengguna (Attitude Toward) aplikasi iSalatiga dengan perilaku untuk menggunakan (Behavioural Intention) aplikasi iSalatiga. apabila pengguna memiliki tekad yang besar untuk menggunakan iSalatiga tentu juga akan memilki keinginan yang besar untuk penggunaan seterusnya, Pengaruh niat perilaku untuk menggunakan
(Behavioral Intention) dengan kondisi sesungguhnya (Actual Use) dalam menggunakan iSalatiga secara real atau nyata. Sehingga apabila adanya banyak keinginan untuk menggunakan aplikasi iSalatiga maka akan akan berdampak pada kondisi sesungguhnya dalam pemakaian atau penggunaan aplikasi iSalatiga secara terus menerus.

\section{SARAN}

Saran yang bisa diberikan dari penelitian ini ialah Dinas Perpustakaan dan Kearsiapan Kota Salatiga harus lebih rutin mengenalkan aplikasi iSalatiga terhadap pengunjung perpustakaan dan didalam kegiatan-kegiatan atau seminar yang melibatkan sekolah maupun untuk umum sehingga para pengunjung dan masyarakat dapat mengetahui tentang keberadaan dan cara-cara dalam mengoperasikan atau menggunakan aplikasi iSalatiga. Di karenakan sebagian besar responden masih belum mengetahui dan paham secara rinci tentang penggunaan aplikasi iSalatiga. Diharapkan hasil penelitian ini dapat menjadi pengembangan kedepannya untuk meningkatkan layanan pengguna teknologi sistem informasi pada Dinas Perpustakaan Dan Arsip Daerah Kota Salatiga.

\section{DAFTAR PUSTAKA}

Hendro Gunawan, Lynawati. 2018. “Analisis Penerimaan Teknologi Smart city Kota Purwekerto Dengan Model Technology Acceptance Model (TAM)".

Ni Luh Nyoman Sherina Dewi, I Wayan Suartana. 2014. "Analisis Technology Acceptance Model (TAM) Terhadap Pengguna Sistem Informasi di Nusa Dua Beach Hotel \& Spa”.

Fran Sayekti, Pulasna Putarta. 2016. "Technology Acceptance Model (TAM) Dalam Pengujian Model Penerimaan Sistem Informasi Keuangan Daerah".

Wiratna Sujarweni, V. 2015. SPSS Untuk Penelitian. Yogyakarta: Pustaka Baru Press.

Sugiono, 2014. Metode penelitian kuantitatif, kualitatif dan kombinasi. Bandung: Alfabeta.

Creswell, J. W. 2014. Reseacrh Design Qualitativ, Quantitatif and Mixed Methods Approaches, 4 Edition. London:Sage.

Agung Prasetyo Patara. 2016. "Analisis Penerimaan Pengguna Terhadap Aplikasi Salatiga Mobile Library". 